\title{
A Matter of the Heart: The African Clawed Frog Xenopus as a Model for Studying Vertebrate Cardiogenesis and Congenital Heart Defects
}

\author{
Annemarie Hempel and Michael Kühl * \\ Institute of Biochemistry and Molecular Biology, Ulm University, Albert-Einstein-Allee 11, 89081 Ulm, Germany; \\ annemarie.hempel@uni-ulm.de \\ * Correspondence: michael.kuehl@uni-ulm.de; Tel.: +49-731-5002-3283; Fax: +49-731-5002-3277 \\ Academic Editors: Georg Vogler and Rolf Bodmer \\ Received: 18 February 2016; Accepted: 30 May 2016; Published: 4 June 2016
}

\begin{abstract}
The African clawed frog, Xenopus, is a valuable non-mammalian model organism to investigate vertebrate heart development and to explore the underlying molecular mechanisms of human congenital heart defects (CHDs). In this review, we outline the similarities between Xenopus and mammalian cardiogenesis, and provide an overview of well-studied cardiac genes in Xenopus, which have been associated with congenital heart conditions. Additionally, we highlight advantages of modeling candidate genes derived from genome wide association studies (GWAS) in Xenopus and discuss commonly used techniques.
\end{abstract}

Keywords: Xenopus; heart development; congenital heart defects; morpholino; model organism

\section{Advantages of Xenopus as a Model Organism}

In the last decades, studies in amphibians such as the African clawed frog Xenopus laevis have substantially contributed to deciphering the mechanisms of early vertebrate heart development. Xenopus and humans share various anatomical, physiological as well as genetic similarities [1,2] suggesting that they have comparable underlying gene regulatory networks [1,3]. Several features make Xenopus an attractive model for studying cardiovascular development and disease. First, Xenopus husbandry is simple and breeding can be done year-round by inducing females to spawn after injection of human chorionic gonadotropin. The litter size can be as high as 2000 eggs per day per frog and embryos can be obtained by in vitro fertilization [3]. In addition, in vitro fertilization allows the synchronization of embryonic development between sibling embryos. Developmental stages of Xenopus laevis embryogenesis have been described and well characterized [4]. Second, the eggs are rather large, about $1.2 \mathrm{~mm}$ in diameter, which makes them suitable for surgical micromanipulation. Third, the extrauterine development of the embryos and detailed fate-maps [5-7] allow tissue-specific manipulations like microinjections or mechanistic analysis in explant assays. Fourth, the partial transparency of the embryos makes them amenable to imaging of the heart. Lastly, early embryos are capable of developing to early tadpole stages in the absence of a working circulation system. This is advantageous because, unlike in mammalian models, it enables the study of early cardiovascular defects in vivo that are not complicated by secondary effects resulting from lack of circulation.

The aforementioned advantages of using Xenopus as a model system are complemented by various molecular techniques. Detailed gene expression maps of molecular cardiac markers for the specific cardiac lineages and the different stages of cardiogenesis are available [8] and enable researchers to monitor gene expression in functional studies by in situ hybridization. Additionally, immunohistochemistry assays can be applied to analyze gene products at the protein level. Regarding functional assays, antisense morpholino oligonucleotides (MOs), cardiac explants and transgenesis are 
currently the main tools in Xenopus research (see next section). With respect to MO based strategies and novel genome editing approaches, it is noteworthy to mention that Xenopus laevis is tetraploid whereas the related Xenopus tropicalis is diploid.

\section{Tool Kit for Studying Heart Development and Diseases in Xenopus}

Xenopus embryos are particularly amenable to microinjections and microsurgery allowing functional assessment of a gene of interest. Genes can be over-expressed by injection of in vitro synthesized mRNA [9], while morpholino oligonucleotides (MOs) approaches offer the possibility to easily generate loss-of-function phenotypes. MOs are highly stable, non-toxic, synthetic nucleic acid analogues, which are not degraded by endogenous nucleases [10-12]. MOs hybridize to their complementary mRNA, thereby blocking translation or interfering with mRNA splicing. MOs have several benefits (reviewed in [13-15]) that include tissue-specific loss-of-function studies with dose-response effects. MOs can target multiple gene products allowing examination of functional gene redundancy. Additionally, multiple knockdowns by combinational MO injections combined with corresponding rescue experiments can unravel epistatic relationships of interacting genes. Since MOs target maternal and zygotic mRNAs simultaneously, they can be used to analyze maternal gene products as long as no corresponding maternal protein has been deposited. Furthermore, the Stainier group reported that morphants do not appear to induce gene compensatory mechanisms to the same extent as mutants do [16]. Recently, the specificity of MOs has been controversially discussed, especially in the zebrafish field $[17,18]$. However, several guidelines for control experiments $[13,19]$ can be adhered to, which should ensure MO specificity and may prevent some of the MOs' pitfalls. Thus, MO applications were and still are a valuable tool for Xenopus research and have enabled vast progress in understanding the molecular mechanisms during development in the last two decades.

A fundamental technique to study molecules with respect to their function in heart development is the use of explanted tissue from Xenopus embryos [14,15,20]. These explants include dorsal marginal zone (DMZ), ventral marginal zone (VMZ) and animal cap explants. During normal embryogenesis, heart precursor cells are specified bilaterally adjacent to the Spemann organizer in the mesodermal germ layer on the dorsal side. Therefore, explants of this region can be used to test for factors that impede cardiac tissue development and to gain deeper insights into the underlying molecular mechanisms directing cardiogenesis [21-24]. In contrast, the ventral mesoderm in Xenopus develops into blood. Accordingly, VMZ explants can be used to test the ability of factors to induce cardiogenesis from non-cardiac specified tissue [21,23,25]. Finally, explants of the animal cap represent a population of pluripotent progenitor cells [14]. Thus, animal caps can be used to analyze which transcription factors and signaling molecules influence cardiac gene expression and differentiation [20].

In addition to $\mathrm{MO}$ and tissue explant techniques, the use of transgenic frogs allows for investigating promoters and tissue-specific gene expression. The first approaches to generating transgenic frogs involved microinjections of DNA resulting in mosaic animals [26]. A few years later, techniques such as Restriction Enzyme Mediated Integration, REMI, through sperm nuclei transplantation or the use of transposable elements, like the Tol2 transposon, were used to establish transgenic frogs (reviewed in [14,15,27]).

The advent of new genome editing tools such as the clustered regulatory inter-spaced short palindromic repeat (CRISPR)/Cas system extend the available toolbox for Xenopus [28,29]. First data derived from $X$. tropicalis show that the majority of CRISPR/Cas9 derived mutants phenocopy MO knockdowns [28]. Unpublished data from Xenopus laevis also suggest promising advances as well, however, the future will show how amenable this technique is.

Finally, cardiac anatomical morphologies can be easily visualized by histological sections and standard microscopy techniques or by in vivo imaging. Advancements in imaging technology such as in echocardiography [30] potentially allow not only 3D but also 4D in vivo imaging of the Xenopus heart in the future, thus enabling more detailed analyses of the morphological changes during heart development and onset of cardiac defects. 


\section{Xenopus as a Model for Vertebrate Cardiogenesis}

The development of the vertebrate heart is a highly conserved, well-orchestrated process that involves cell specification and differentiation along with extensive morphogenetic remodeling of the cardiac tissue. Early cardiogenesis has been analyzed in Xenopus through a combination of fate mapping approaches [5-7], transplant experiments [24,31], gene expression analyses [8], histological sections and whole mount confocal microscopy or immunohistochemistry and 3D reconstruction $[32,33]$. While mammals and birds have a four-chambered heart consisting of two atria and two ventricles, amphibians have a three-chambered heart with a single ventricle, which resembles the mammalian left ventricle [8]. Thus, the Xenopus heart represents the evolutionary intermediate between the two-chambered fish heart and the four-chambered hearts of birds and mammals. In this section, we summarize the most important steps of Xenopus and murine heart development and highlight the similarities and differences that can be taken advantage of when studying vertebrate cardiogenesis.

Vertebrate cardiogenesis (Figure 1, Table 1) begins at the onset of gastrulation (Xenopus stage 10, mouse E6.5). The heart originates from the precardiac mesoderm that is located bilaterally on the dorsal side of the Xenopus embryo on either side of the Spemann's organizer. In mouse embryos, the cardiac primordia lie on opposite sides of the cranial midline [31,34-36]. Gastrulation movements cause the cardiac progenitors to migrate anteriorly to the ventral midline.

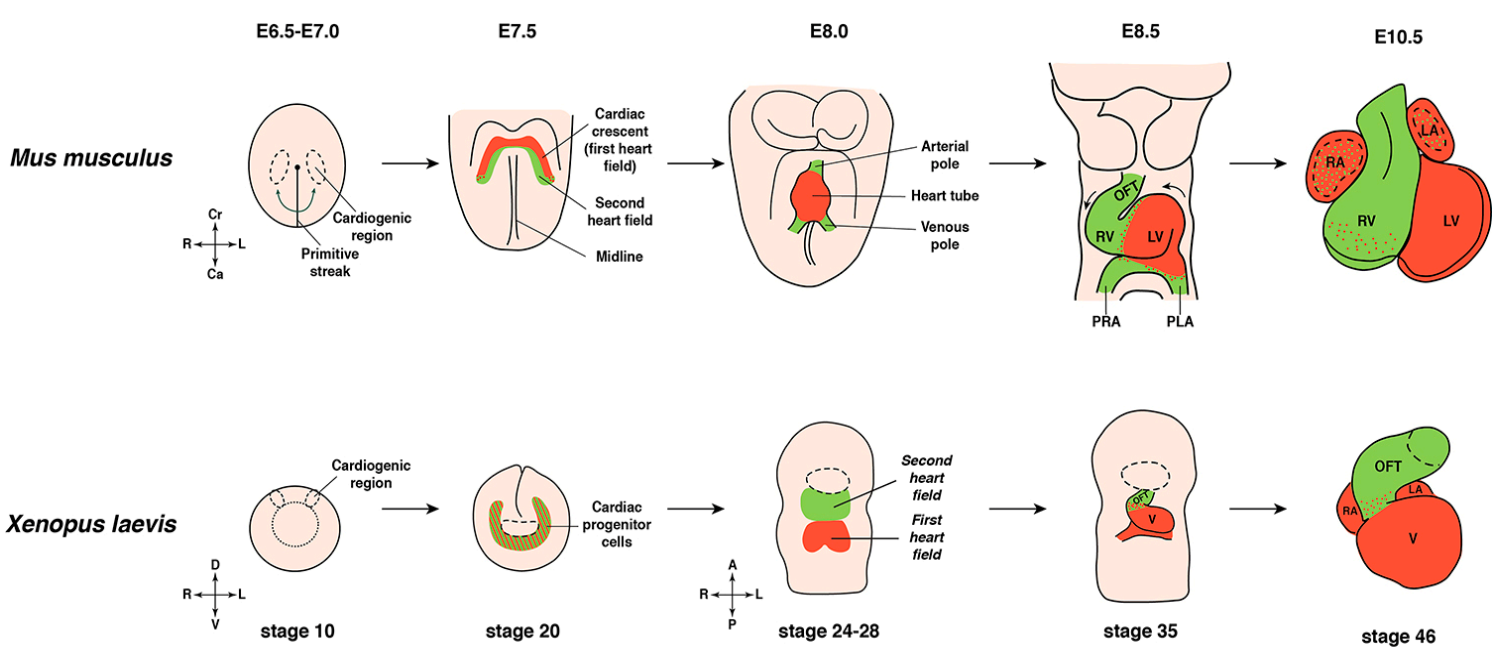

Figure 1. Early cardiogenesis in mouse (upper panel) and Xenopus (lower panel). During gastrulation myocardial progenitor cells arise from the mesoderm and migrate to the ventral midline to the anterior part of the embryo. The progenitor cells form the cardiac crescent (first heart field), which already includes differentiated cardiomyocytes. The primary heart tube is formed at the ventral midline, starts to beat and undergoes looping and further morphological remodeling. Subsequently, the different cardiac chambers are formed. Cr-Ca/D-V/A-P and R-L axes are indicated. A: anterior; Ca, caudal; Cr: cranial; D: dorsal; L: left; LA: left atrium; LV: left ventricle; OFT: outflow tract; PLA: primitive left atrium; P: posterior; PRA: primitive right atrium; R: right; RA: right atrium; RV: right ventricle; $\mathrm{V}$ : ventral.

The common cardiac progenitor cells fuse at the ventral midline immediately posterior to the cement gland in Xenopus and from a crescent-like structure until stage 13 (Xenopus). This common cardiac progenitor cell population splits into two different lineages, also referred to as the first heart field (FHF) cell lineage and the second heart field (SHF) cell lineage [37,38]. In mouse, cells of the FHF contribute to the left ventricular myocardial cells, [39] and the two atria [40,41]. The SHF mainly forms the myocardium of the outflow tract (OFT) [42] but also contributes to the right ventricle [43]. In contrast, the Xenopus SHF only contributes to the OFT and the FHF forms into the single ventricle 
and the two atria of the heart. These two lineages can be distinguished by marker gene expression by E7.5 in the mouse and stage 24 in Xenopus. A widely used marker gene for the SHF also in Xenopus is the transcription factor Islet $1[44,45]$, whereas Tbx 5 is one common marker of the FHF at this stage [46].

Eventually, the heart primodia merge and form the primary heart tube (Xenopus stage 31-33, mouse E8.0). Subsequently, the heart tube undergoes rightward looping (Xenopus stage 33-36, mouse E8.5) and the myocardium expands. At this point, the heart tube contains differentiated cardiomyocytes and begins to contract (Xenopus stage 35, mouse E8.5). After looping, the heart compartmentalizes into well-defined chambers (Xenopus stage 40-46, mouse E10.5). During this remodeling phase, the ventricular myocardium also undergoes trabeculation [15,32,33,37,47-50]. Considering these morphological as well as molecular similarities to the mammalian heart, Xenopus provides a valuable model for studying the underlying molecular mechanisms for the formation of the cardiovascular system and the progression of associated diseases.

Table 1. Comparative timeline of events in cardiovascular development in different species. Based on $[8,15,50-54]$.

\begin{tabular}{|c|c|c|c|c|c|}
\hline \multirow{2}{*}{ Cardiovascular Event } & \multicolumn{5}{|c|}{ Developmental Stage } \\
\hline & Danio Rerio & Xenopus Laevis & Mus Musculus & Gallus Gallus & Homo Sapiens \\
\hline cardiac progenitors & $5 \mathrm{hpf}$ & NF10 & E6.5 & $\mathrm{HH} 4$ & CS7 \\
\hline heart field specification & $12 \mathrm{hpf}$ & NF12-NF14 & E7.0-E7.5 & HH5 & CS8 \\
\hline migration to ventral midline & $12-19 \mathrm{hpf}$ & NF12-NF13 & E7.5 & HH7-HH8 & CS9 \\
\hline $\begin{array}{l}\text { primary heart } \\
\text { tube formation }\end{array}$ & $21-24 \mathrm{hpf}$ & NF31-NF33 & E8.0 & HH9 & CS10 \\
\hline $\begin{array}{l}\text { onset of coordinated } \\
\text { muscle contraction }\end{array}$ & $22 \mathrm{hpf}$ & NF35 & E8.5 & HH10 & CS10 \\
\hline cardiac looping & $30-36$ hpf & NF33-NF36 & E8.5-E10.5 & HH10-HH24 & CS13-CS17 \\
\hline onset of blood flow & $30 \mathrm{hpf}$ & NF35 & E8.5 & HH10 & CS11 \\
\hline chamber formation & $30 \mathrm{hpf}$ & NF39-NF40 & E9.5-E12.5 & HH16/17 & CS12-CS15 \\
\hline $\begin{array}{l}\text { onset of ventricular } \\
\text { trabeculaetion }\end{array}$ & $48 \mathrm{hpf}$ & NF41 & E9.5 & HH16 & CS11 \\
\hline valvulogenesis & $48 \mathrm{hpf}$ & NF41-NF44 & E9.5 & HH21-HH36 & CS15-CS18 \\
\hline atrial septation & none & NF44-NF45 & E10.0-E14.5 & HH16-HH36 & CS14-CS18 \\
\hline ventricular septation & none & none & E9.0-E14.0 & HН17-HН34 & CS16-CS22 \\
\hline
\end{tabular}

hpf: hour(s) post fertilization; NF: stages according to Nieuwkoop and Faber, 1956; E: embryonic day; HH: stages according to Hamburger and Hamilton, 1951; CS: Carnegie stages.

\section{Xenopus Models for Human Congenital Heart Defects}

Aberrations in heart development are associated with numerous human congenital heart defects (CHDs) [55]. CHDs are the most common disorder in newborns with a prevalence of approximately $1 \%$ in live births and cause about $10 \%$ of stillbirths and spontaneous abortions [56,57]. Mutations in e.g., NKX2.5, GATA or T-BOX genes in patients are associated with CHDs such as atrial septal defects, DiGeorge Syndrome or Tetralogy of Fallot, to name a few. Several distinct characteristics of Xenopus emphasize its suitability for modeling CHDs when compared to other model systems. For example, gene function can be quickly analyzed due to the rapid embryonic development of Xenopus. As embryos develop in the absence of a functional circulation system, the onset of cardiovascular defects can be investigated in vivo. The three-chambered heart is not a disadvantage since the ventricle resembles the mammalian left ventricle [8] and allows for modeling of, e.g., hypoplastic left heart syndrome defects (HLHS). In contrast to zebrafish, the septated atria in the Xenopus heart allow for the study of atrial septal defects.

In recent years, more and more Xenopus models have emerged and the data from these models has complemented studies that used genetically modified mice as well as murine and human iPS cells (Table 2) [reviewed in 14]. In the following section, we briefly describe selected Xenopus models. For a 
more detailed description of the Xenopus models for human CHDs, we refer the reader to an excellent review from the Conlon group [14].

Table 2. Selected Xenopus models for human CHDs (see main text for details).

\begin{tabular}{|c|c|c|c|}
\hline Disease & Affected Genes & Xenopus Model & Cardiovascular Phenotype \\
\hline \multirow{2}{*}{ Atrial Septal Defects (ASD) } & gata4 & LOF & looping defects \\
\hline & $n k x 2-5$ & GOF & cardiac conduction defects, ASD \\
\hline Axonfeld-Reiger Syndrome & pitx2 & GOF, LOF & looping defects and ASD \\
\hline CHARGE Syndrome & $\operatorname{chd} 7$ & GOF, LOF & neural cest migration and OFT defects \\
\hline DiGeorge Syndrome & $t b x 1$ & GOF & looping defects \\
\hline Holt-Oram Syndrome & $t b x 5$ & GOF, LOF & looping defects, reduced cardiomyocytes \\
\hline Jacobsen Syndrome & ets1 & LOF & OFT and aortic arch formation defects \\
\hline $\begin{array}{c}\text { LVOT obstructive defects, } \\
\text { Hypoplastic left heart syndrome }\end{array}$ & mctp2 & GOF, LOF & looping defects, OFT defects \\
\hline Tetralogy of Fallot & $t b x 20$ & LOF & looping defects, reduced cardiomyocytes \\
\hline
\end{tabular}

Atrial septal defects (ASDs) are one of the most common CHDs. An atrial septal defect is characterized by an incomplete separation of left and right atrium by atrial septum, which thereby allows oxygen-rich and oxygen-poor blood to mix. Several ASD patients have been identified with changes in the NKX2.5 protein $[58,59]$ and its interacting partner, the zinc finger transcription factor GATA4 [60-63]. In patients, several point mutations in NKX2.5 have been identified. Overexpression of $\mathrm{Nkx2.5}$ constructs carrying these mutations in Xenopus resulted in ASDs and conduction system defects that recapitulated the cardiac defects observed in patients [59,64]. Furthermore, knockdown of gata4 via $\mathrm{MO}$ approach causes a strong reduction in heart precursor cells during cardiac specification and later defects in heart morphology. Furthermore, it has been proposed that GATA4, GATA5 and GATA6 function redundantly to regulate myocardial differentiation $[65,66]$. In mice, it has been shown that, for normal cardiac morphogenesis, the interaction between Gata4 and Tbx 5 is critical [67]. Mutations in the T-box transcription factor TBX5 account for more than $70 \%$ of patients with Holt-Oram Syndrome (HOS), which is characterized by ASDs, ventricular septal defects (VSDs) and cardiac conduction defects [68-71]. Overexpression of a dominant-negative Tbx5 protein in Xenopus inhibited heart tube formation. In contrast, loss of Tbx 5 function caused unlooped heart tubes and decreased cardiac cell numbers due to decreased cell cycle progression. Thus, defects in cell proliferation probably cause cardiac defects, phenocopying defects of HOS patients [72-74].

Mutations in other members of the T-box family are accountable for other CHDs as well. Several mutations identified in TBX20 contribute to familial CHD or congenital ASD [75-79]. In some Tetralogy of Fallot patients, Tbx20 is upregulated [80]. Recent studies in Xenopus showed that Tbx20 does not affect cardiac specification and differentiation. However, depletion of Tbx20 resulted in unlooped heart tubes, pericardial edema, defects in chamber formation and reduced cardiomyocyte numbers [72]. Moreover, overexpression analyses in Xenopus embryos and animal caps revealed that TBX20 activity depends on its C-terminal domain [81]. Brown et al. demonstrated that TBX20 physically interacts with TBX5. Therefore, it is not surprising that the combined depletion of Tbx20 and Tbx5 in Xenopus resulted in more severe cardiac defects than loss of either one alone [72].

DiGeorge Syndrome or 22q11 deletion syndrome (del22q11DS) is characterized by symptoms such as Tetralogy of Fallot and cardio-facial abnormalities. The deletion includes the locus of the T-box gene TBX1 [82-84]. Furthermore, several mutations in TBX1 have been identified in patients with DiGeorge Syndrome phenotypes [85]. Overexpression of a dominant interfering mutant of $t b x 1$ in Xenopus resulted in unlooped hearts and pericardial edema $[86,87]$ similar to the cardiac defects observed in patients. 
Jacobsen syndrome (11q-) describes a rare condition caused by deletion of the distal part of chromosome 11 and includes many common CHDs, ventricular septum defect (VSD) as well as HLHS [88-91]. One gene in the deleted region is a member of the ETS family of transcription factors, ETS-1 [92]. A study in Xenopus discovered that Ets1 is required for cardiac neural crest and mesoderm formation. Depletion of Ets1 in cardiac neural crest tissue resulted in smaller, malformed OFTs analogous to defects of DiGeorge syndrome patients. Disruption of Ets1 via MO knockdown in the cardiac mesoderm delayed heart tube formation and impaired heart morphogenesis resulting in the loss of the three-chambered heart shape. Ets1-MO treated embryos had a single chamber heart with misshaped OFTs, an underdeveloped ventricle and a defective aortic arch formation resembling defects of HLHS patients. Due to reduced expression of $t b x 1$ and mef2 in Ets1 morphants, it has been suggested that Tbx1 might be a direct target of Ets 1 in the cardiac mesoderm and thus maybe partially responsible for the patients phenotype [93].

In 2013, novel gene variants in HLHS patients with left ventricular outflow tract (LVOT) conduction defects were identified in MCTP2 (multiple C2-domains with two transmembrane regions 2) [94]. Gain and loss of Mctp2 function in Xenopus resulted in perturbed cardiac development with OFT defects in a dosage-sensitive manner. Mctp2 morphants exhibited pericardial edema, looping and OFT defects and failed to form endocardial cushion reminiscent for LVOT defects [94].

Another condition associated with various cardiac malformations is CHARGE syndrome [95], which, in most cases, is caused by heterozygous mutations or deletions of the chromodomain helicase DNA-binding protein 7 (CHD7) [96-101]. CHARGE syndrome patients exhibit Tetralogy of Fallot, aortic arch and atrioventricular canal malformation [95]. Impairment of Chd7 in Xenopus led to cardiac defects reminiscent of CHARGE phenotype including OFT defects and truncus arteriosus abnormalities [102]. It has been demonstrated that Chd7 is crucial for the formation of migratory neural crest cells and regulates gene expression involved in neural crest cell and axon guidance [102,103]. Moreover, Chd7-deficient Xenopus embryos have reduced semaphorin-3a (sema3a) expression suggesting that disturbed sema3a signaling contributes to the pathogenesis of the CHARGE-related disorder Kallmann syndrome and possibly CHARGE syndrome itself [103].

\section{Modeling GWAS Candidates Associated with CHDs in Xenopus}

The first genome-wide association studies (GWAS) for coronary artery disease were published in 2007 [104-106]. Since then, GWAS pinpointed hundreds of genetic factors associated with cardiovascular diseases (CVDs) [107-110]. Also, whole-exome sequencing of patients and their relatives have identified a large set of mutations that are potentially disease causing. The large number of candidate genes derived by these methods generates the problem of separating mutations that are relevant from irrelevant mutations in the associated pathologies. Large-scale screens based on MO-mediated knockdown of gene function can be quickly performed in Xenopus with the aim to verify causal candidate genes $[111,112]$.

Two recent examples shall highlight the suitability of Xenopus for GWAS studies. In 2011, a copy number deletion of the N-acetylgalactosaminyltransferase 11 (GALNT11) gene was identified in a heterotaxy patient [108]. Depletion of Galnt11 in Xenopus resulted in abnormal cardiac looping. Knockdown as well as overexpression of human GALNT11 led to left-right patterning defects, mimicking primary ciliary dyskinesia in humans. The density of multiciliated cells was affected in these embryos caused by a deregulated Notch pathway [113].

Another GWAS associated the human zinc finger transcription factor CASZ1 with hypertension and high systolic blood pressure [114,115]. In Xenopus, Casz1 is required for proper cardiovascular development $[116,117]$ and, therefore, also for the heart's proper physiological function. Depletion of Casz1 caused a subset of cardiac progenitor cells along the ventral midline to arrest. They are maintained as cardiac progenitors and fail to terminally differentiate into cardiomyocytes prior to heart tube formation [117]. Immunofluorescent analyses revealed Casz1 downregulation in cells reentering cell cycle and loss of Casz1 led to an increased mitotic index within cardiomyocytes. Thus, 
Casz1 regulates cell proliferation [118]. The authors hypothesized that Casz1 regulates cardiomyocyte growth and perhaps also their function, thereby influencing the physiological heart function. Casz1 directly interacts with the congenital heart disease 5 protein (CHD5), which is required for cardiac morphogenesis during heart looping and chamber formation. Depletion of CHD5 in Xenopus resulted in improper cardiomyocyte adhesion and deposition of basement membrane within myocardial tissue [119], which could potentially affect the blood pumping efficiency of the heart.

In summary, because of the anatomical, physiological and genetic similarities between Xenopus and mammals, this amphibian is ideally suited to investigate the molecular basis for vertebrate heart development and the progression of cardiac defects. MO-based large scale screening approaches as well as emerging techniques such as genome editing facilitate more in-depth analysis allowing Xenopus to thrive as an early model to investigate CHDs and GWAS candidate genes in the future.

Acknowledgments: We thank Petra Pandur (Ulm) and Melanie Philipp (Ulm) for their comments on the manuscript and Helen Tauc (Ulm) for critical reading.

Author Contributions: AH and MK wrote the article.

Conflicts of Interest: The authors declare no conflict of interest.

Human and Animal Rights and Informed Consent: This article does not contain any studies with human or animal subjects performed by any of the authors. In general, research in our laboratory is performed in accordance with local and German federal animal rights protection regulations.

\section{Abbreviations}

The following abbreviations are used in this manuscript:

$\begin{array}{ll}\text { ASD } & \text { atrial septal defects } \\ \text { CHARGE } & \text { Coloboma, Heart defects, choanal Atresia, Retarded growth and development } \\ \text { CHD } & \text { congenital heart defects } \\ \text { CRISPR } & \text { clustered regulatory inter-spaced short palindromic repeats } \\ \text { DMZ } & \text { dorsal marginal zone } \\ \text { FHF } & \text { first heart field } \\ \text { HLHS } & \text { hypoplastic left heart syndrome } \\ \text { HOS } & \text { Holt-Oram syndrome } \\ \text { LVOT } & \text { left ventricular outflow tract } \\ \text { MO } & \text { morpholino oligonucleotides } \\ \text { OFT } & \text { outflow tract } \\ \text { SHF } & \text { second heart field } \\ \text { VMZ } & \text { ventral marginal zone } \\ \text { VSD } & \text { ventricular septal defects }\end{array}$

\section{References}

1. Wheeler, G.N.; Brandli, A.W. Simple vertebrate models for chemical genetics and drug discovery screens: Lessons from zebrafish and xenopus. Dev. Dyn. 2009, 238, 1287-1308. [CrossRef] [PubMed]

2. Schmitt, S.M.; Gull, M.; Brandli, A.W. Engineering Xenopus embryos for phenotypic drug discovery screening. Adv. Drug Deliv. Rev. 2014, 69-70, 225-246. [CrossRef] [PubMed]

3. Blitz, I.L.; Andelfinger, G.; Horb, M.E. Germ layers to organs: Using xenopus to study "later" development. Semin. Cell Dev. Biol. 2006, 17, 133-145. [CrossRef] [PubMed]

4. Nieuwkoop, P.D.; Faber, J. Normal Table of Xenopus Laevis (Daudin); a Systematical and Chronological Survey of the Development From the Fertilized Egg Till the End of Metamorphosis; North-Holland Publishing Co.: Amsterdam, The Netherlands, 1956; p. 243.

5. Dale, L.; Slack, J.M. Fate map for the 32-cell stage of Xenopus laevis. Development 1987, 99, 527-551. [PubMed]

6. Keller, R.E. Vital dye mapping of the gastrula and neurula of Xenopus laevis: II. Prospective areas and morphogenetic movements of the deep layer. Dev. Biol. 1976, 51, 118-137. [CrossRef]

7. Moody, S.A. Fates of the blastomeres of the 32-cell-stage Xenopus embryo. Dev. Biol. 1987, 122, $300-319$. [CrossRef] 
8. Gessert, S.; Kuhl, M. Comparative gene expression analysis and fate mapping studies suggest an early segregation of cardiogenic lineages in Xenopus laevis. Dev. Biol. 2009, 334, 395-408. [CrossRef] [PubMed]

9. Cleaver, O.; Krieg, P.A. Expression from DNA injected into Xenopus embryos. Methods Mol. Biol. 1999, 127, 133-153. [PubMed]

10. Tandon, P.; Showell, C.; Christine, K.; Conlon, F.L. Morpholino injection in xenopus. Methods Mol. Biol. 2012, 843, 29-46. [PubMed]

11. Summerton, J. Morpholino antisense oligomers: The case for an RNase H-independent structural type. Biochim. Biophys. Acta 1999, 1489, 141-158. [CrossRef]

12. Summerton, J.E. Morpholino, sirna, and s-DNA compared: Impact of structure and mechanism of action on off-target effects and sequence specificity. Curr. Top Med. Chem. 2007, 7, 651-660. [CrossRef] [PubMed]

13. Blum, M.; De Robertis, E.M.; Wallingford, J.B.; Niehrs, C. Morpholinos: Antisense and sensibility. Dev. Cell 2015, 35, 145-149. [CrossRef] [PubMed]

14. Kaltenbrun, E.; Tandon, P.; Amin, N.M.; Waldron, L.; Showell, C.; Conlon, F.L. Xenopus: An emerging model for studying congenital heart disease. Birth Defects Res. A 2011, 91, 495-510. [CrossRef] [PubMed]

15. Warkman, A.S.; Krieg, P.A. Xenopus as a model system for vertebrate heart development. Semin. Cell Dev. Biol. 2007, 18, 46-53. [CrossRef] [PubMed]

16. Rossi, A.; Kontarakis, Z.; Gerri, C.; Nolte, H.; Holper, S.; Kruger, M.; Stainier, D.Y. Genetic compensation induced by deleterious mutations but not gene knockdowns. Nature 2015, 524, 230-233. [CrossRef] [PubMed]

17. Kok, F.O.; Shin, M.; Ni, C.W.; Gupta, A.; Grosse, A.S.; van Impel, A.; Kirchmaier, B.C.; Peterson-Maduro, J.; Kourkoulis, G.; Male, I.; et al. Reverse genetic screening reveals poor correlation between morpholinoinduced and mutant phenotypes in zebrafish. Dev. Cell 2015, 32, 97-108. [CrossRef] [PubMed]

18. Schulte-Merker, S.; Stainier, D.Y. Out with the old, in with the new: Reassessing morpholino knockdowns in light of genome editing technology. Development 2014, 141, 3103-3104. [CrossRef] [PubMed]

19. Eisen, J.S.; Smith, J.C. Controlling morpholino experiments: Don't stop making antisense. Development 2008, 135, 1735-1743. [CrossRef] [PubMed]

20. Afouda, B.A.; Hoppler, S. Xenopus explants as an experimental model system for studying heart development. Trends Cardiovasc. Med. 2009, 19, 220-226. [CrossRef] [PubMed]

21. Afouda, B.A.; Martin, J.; Liu, F.; Ciau-Uitz, A.; Patient, R.; Hoppler, S. GATA transcription factors integrate wnt signalling during heart development. Development 2008, 135, 3185-3190. [CrossRef] [PubMed]

22. Foley, A.C.; Mercola, M. Heart induction by wnt antagonists depends on the homeodomain transcription factor hex. Genes dev. 2005, 19, 387-396. [CrossRef] [PubMed]

23. Schneider, V.A.; Mercola, M. Wnt antagonism initiates cardiogenesis in Xenopus laevis. Genes Dev. 2001, 15, 304-315. [CrossRef] [PubMed]

24. Sater, A.K.; Jacobson, A.G. The role of the dorsal lip in the induction of heart mesoderm in Xenopus laevis. Development 1990, 108, 461-470. [PubMed]

25. Pandur, P.; Lasche, M.; Eisenberg, L.M.; Kuhl, M. Wnt-11 activation of a non-canonical wnt signalling pathway is required for cardiogenesis. Nature 2002, 418, 636-641. [CrossRef] [PubMed]

26. Etkin, L.D.; Pearman, B. Distribution, expression and germ line transmission of exogenous DNA sequences following microinjection into Xenopus laevis eggs. Development 1987, 99, 15-23. [PubMed]

27. Takagi, C.; Sakamaki, K.; Morita, H.; Hara, Y.; Suzuki, M.; Kinoshita, N.; Ueno, N. Transgenic Xenopus laevis for live imaging in cell and developmental biology. Dev. Growth Differ. 2013, 55, 422-433. [CrossRef] [PubMed]

28. Bhattacharya, D.; Marfo, C.A.; Li, D.; Lane, M.; Khokha, M.K. Crispr/cas9: An inexpensive, efficient loss of function tool to screen human disease genes in xenopus. Dev. Biol. 2015, 408, 196-204. [CrossRef] [PubMed]

29. Tandon, P.; Conlon, F.; Furlow, J.D.; Horb, M.E. Expanding the genetic toolkit in xenopus: Approaches and opportunities for human disease modeling. Dev. Biol. 2016. [CrossRef] [PubMed]

30. Bartlett, H.L.; Escalera, R.B., 2nd; Patel, S.S.; Wedemeyer, E.W.; Volk, K.A.; Lohr, J.L.; Reinking, B.E. Echocardiographic assessment of cardiac morphology and function in xenopus. Comp. Med. 2010, 60, 107-113. [PubMed]

31. Sater, A.K.; Jacobson, A.G. The specification of heart mesoderm occurs during gastrulation in Xenopus laevis. Development 1989, 105, 821-830. [PubMed]

32. Kolker, S.J.; Tajchman, U.; Weeks, D.L. Confocal imaging of early heart development in Xenopus laevis. Dev. Biol. 2000, 218, 64-73. [CrossRef] [PubMed] 
33. Mohun, T.J.; Leong, L.M.; Weninger, W.J.; Sparrow, D.B. The morphology of heart development in Xenopus laevis. Dev. Biol. 2000, 218, 74-88. [CrossRef] [PubMed]

34. Nascone, N.; Mercola, M. An inductive role for the endoderm in xenopus cardiogenesis. Development 1995, 121, 515-523. [PubMed]

35. Lawson, K.A.; Meneses, J.J.; Pedersen, R.A. Clonal analysis of epiblast fate during germ layer formation in the mouse embryo. Development 1991, 113, 891-911. [PubMed]

36. Tam, P.P.; Parameswaran, M.; Kinder, S.J.; Weinberger, R.P. The allocation of epiblast cells to the embryonic heart and other mesodermal lineages: The role of ingression and tissue movement during gastrulation. Development 1997, 124, 1631-1642. [PubMed]

37. Buckingham, M.; Meilhac, S.; Zaffran, S. Building the mammalian heart from two sources of myocardial cells. Nat. Rev. Genet. 2005, 6, 826-835. [CrossRef] [PubMed]

38. Engleka, K.A.; Manderfield, L.J.; Brust, R.D.; Li, L.; Cohen, A.; Dymecki, S.M.; Epstein, J.A. Islet1 derivatives in the heart are of both neural crest and second heart field origin. Circ. Res. 2012, 110, 922-926. [CrossRef] [PubMed]

39. O'Brien, T.X.; Lee, K.J.; Chien, K.R. Positional specification of ventricular myosin light chain 2 expression in the primitive murine heart tube. Proc. Natl. Acad. Sci. USA 1993, 90, 5157-5161. [CrossRef] [PubMed]

40. Meilhac, S.M.; Esner, M.; Kelly, R.G.; Nicolas, J.F.; Buckingham, M.E. The clonal origin of myocardial cells in different regions of the embryonic mouse heart. Dev. Cell 2004, 6, 685-698. [CrossRef]

41. Kelly, R.G.; Brown, N.A.; Buckingham, M.E. The arterial pole of the mouse heart forms from fgf10-expressing cells in pharyngeal mesoderm. Dev. Cell 2001, 1, 435-440. [CrossRef]

42. Kelly, R.G.; Buckingham, M.E. The anterior heart-forming field: Voyage to the arterial pole of the heart. Trends Genet. 2002, 18, 210-216. [CrossRef]

43. Zaffran, S.; Kelly, R.G.; Meilhac, S.M.; Buckingham, M.E.; Brown, N.A. Right ventricular myocardium derives from the anterior heart field. Circ. Res. 2004, 95, 261-268. [CrossRef] [PubMed]

44. Brade, T.; Gessert, S.; Kuhl, M.; Pandur, P. The amphibian second heart field: Xenopus islet-1 is required for cardiovascular development. Dev. Biol. 2007, 311, 297-310. [CrossRef] [PubMed]

45. Pandur, P.; Sirbu, I.O.; Kuhl, S.J.; Philipp, M.; Kuhl, M. Islet1-expressing cardiac progenitor cells: A comparison across species. Dev. Genes Evol. 2013, 223, 117-129. [CrossRef] [PubMed]

46. Herrmann, F.; Bundschu, K.; Kuhl, S.J.; Kuhl, M. Tbx5 overexpression favors a first heart field lineage in murine embryonic stem cells and in Xenopus laevis embryos. Dev. Dyn. Off. Publ. Am. Assoc. Anat. 2011, 240, 2634-2645. [CrossRef] [PubMed]

47. Harvey, R.P. Patterning the vertebrate heart. Nat. Rev. Genet. 2002, 3, 544-556. [CrossRef] [PubMed]

48. Laugwitz, K.L.; Moretti, A.; Caron, L.; Nakano, A.; Chien, K.R. Islet1 cardiovascular progenitors: A single source for heart lineages? Development 2008, 135, 193-205. [CrossRef] [PubMed]

49. Abu-Issa, R.; Kirby, M.L. Heart field: From mesoderm to heart tube. Annu. Rev. Cell Dev. Biol. 2007, 23, 45-68. [CrossRef] [PubMed]

50. Lohr, J.L.; Yost, H.J. Vertebrate model systems in the study of early heart development: Xenopus and zebrafish. Am. J. Med. Genet. 2000, 97, 248-257. [CrossRef]

51. Kowalski, W.J.; Pekkan, K.; Tinney, J.P.; Keller, B.B. Investigating developmental cardiovascular biomechanics and the origins of congenital heart defects. Front. Physiol. 2014, 5, 408. [CrossRef] [PubMed]

52. Krishnan, A.; Samtani, R.; Dhanantwari, P.; Lee, E.; Yamada, S.; Shiota, K.; Donofrio, M.T.; Leatherbury, L.; Lo, C.W. A detailed comparison of mouse and human cardiac development. Pediatr. Res. 2014, 76, 500-507. [CrossRef] [PubMed]

53. Schoenwolf, G.C.; Bleyl, S.B.; Brauer, P.R.; Francis-West, P.H. Development of the Heart. In Larsen's Human Embryology, 5th ed.; Churchill Livingstone, an imprint of Elsevier Inc.: Philadelphia, PA, USA, 2015; Chapter 12; pp. 267-303.

54. Martinsen, B.J. Reference guide to the stages of chick heart embryology. Dev. Dyn. 2005, 233, 1217-1237. [CrossRef] [PubMed]

55. Srivastava, D. Genetic regulation of cardiogenesis and congenital heart disease. Annu. Rev. Pathol. 2006, 1, 199-213. [CrossRef] [PubMed]

56. Hoffman, J.I. Incidence of congenital heart disease: II. Prenatal incidence. Pediatr. Cardiol. 1995, 16, 155-165. [CrossRef] [PubMed] 
57. Hoffman, J.I. Incidence of congenital heart disease: I. Postnatal incidence. Pediatr. Cardiol. 1995, 16, $103-113$. [CrossRef] [PubMed]

58. Benson, D.W.; Silberbach, G.M.; Kavanaugh-McHugh, A.; Cottrill, C.; Zhang, Y.; Riggs, S.; Smalls, O.; Johnson, M.C.; Watson, M.S.; Seidman, J.G.; et al. Mutations in the cardiac transcription factor nkx2.5 affect diverse cardiac developmental pathways. J. Clin. Investig. 1999, 104, 1567-1573. [CrossRef] [PubMed]

59. Schott, J.J.; Benson, D.W.; Basson, C.T.; Pease, W.; Silberbach, G.M.; Moak, J.P.; Maron, B.J.; Seidman, C.E.; Seidman, J.G. Congenital heart disease caused by mutations in the transcription factor nkx2-5. Science 1998, 281, 108-111. [CrossRef] [PubMed]

60. Durocher, D.; Charron, F.; Warren, R.; Schwartz, R.J.; Nemer, M. The cardiac transcription factors Nkx2-5 and GATA-4 are mutual cofactors. EMBO J. 1997, 16, 5687-5696. [CrossRef] [PubMed]

61. Lee, Y.; Shioi, T.; Kasahara, H.; Jobe, S.M.; Wiese, R.J.; Markham, B.E.; Izumo, S. The cardiac tissue-restricted homeobox protein Csx/Nkx2.5 physically associates with the zinc finger protein GATA4 and cooperatively activates atrial natriuretic factor gene expression. Mol. Cell. Biol. 1998, 18, 3120-3129. [CrossRef] [PubMed]

62. Pehlivan, T.; Pober, B.R.; Brueckner, M.; Garrett, S.; Slaugh, R.; Van Rheeden, R.; Wilson, D.B.; Watson, M.S.; Hing, A.V. Gata4 haploinsufficiency in patients with interstitial deletion of chromosome region 8p23.1 and congenital heart disease. Am. J. Med. Genet. 1999, 83, 201-206. [CrossRef]

63. Sepulveda, J.L.; Belaguli, N.; Nigam, V.; Chen, C.Y.; Nemer, M.; Schwartz, R.J. GATA-4 and Nkx-2.5 coactivate Nkx-2 DNA binding targets: Role for regulating early cardiac gene expression. Mol. Cell. Biol. 1998, 18, 3405-3415. [CrossRef] [PubMed]

64. Bartlett, H.L.; Sutherland, L.; Kolker, S.J.; Welp, C.; Tajchman, U.; Desmarais, V.; Weeks, D.L. Transient early embryonic expression of Nkx2-5 mutations linked to congenital heart defects in human causes heart defects in Xenopus laevis. Dev. Dyn. 2007, 236, 2475-2484. [CrossRef] [PubMed]

65. Haworth, K.E.; Kotecha, S.; Mohun, T.J.; Latinkic, B.V. GATA4 and GATA5 are essential for heart and liver development in Xenopus embryos. BMC Dev. Biol. 2008, 8, 74. [CrossRef] [PubMed]

66. Peterkin, T.; Gibson, A.; Patient, R. Redundancy and evolution of gata factor requirements in development of the myocardium. Dev. Biol. 2007, 311, 623-635. [CrossRef] [PubMed]

67. Maitra, M.; Schluterman, M.K.; Nichols, H.A.; Richardson, J.A.; Lo, C.W.; Srivastava, D.; Garg, V. Interaction of Gata4 and Gata6 with Tbx5 is critical for normal cardiac development. Dev. Biol. 2009, 326, 368-377. [CrossRef] [PubMed]

68. Basson, C.T.; Cowley, G.S.; Solomon, S.D.; Weissman, B.; Poznanski, A.K.; Traill, T.A.; Seidman, J.G.; Seidman, C.E. The clinical and genetic spectrum of the holt-oram syndrome (heart-hand syndrome). N. Engl. J. Med. 1994, 330, 885-891. [CrossRef] [PubMed]

69. Cross, S.J.; Ching, Y.H.; Li, Q.Y.; Armstrong-Buisseret, L.; Spranger, S.; Lyonnet, S.; Bonnet, D.; Penttinen, M.; Jonveaux, P.; Leheup, B.; et al. The mutation spectrum in holt-oram syndrome. J. Med. Genet. 2000, 37, 785-787. [CrossRef] [PubMed]

70. Holt, M.; Oram, S. Familial heart disease with skeletal malformations. Br. Heart J. 1960, 22, $236-242$. [CrossRef] [PubMed]

71. McDermott, D.A.; Bressan, M.C.; He, J.; Lee, J.S.; Aftimos, S.; Brueckner, M.; Gilbert, F.; Graham, G.E.; Hannibal, M.C.; Innis, J.W.; et al. Tbx5 genetic testing validates strict clinical criteria for holt-oram syndrome. Pediatr. Res. 2005, 58, 981-986. [CrossRef] [PubMed]

72. Brown, D.D.; Martz, S.N.; Binder, O.; Goetz, S.C.; Price, B.M.; Smith, J.C.; Conlon, F.L. Tbx5 and tbx20 act synergistically to control vertebrate heart morphogenesis. Development 2005, 132, 553-563. [CrossRef] [PubMed]

73. Goetz, S.C.; Brown, D.D.; Conlon, F.L. Tbx5 is required for embryonic cardiac cell cycle progression. Development 2006, 133, 2575-2584. [CrossRef] [PubMed]

74. Horb, M.E.; Thomsen, G.H. Tbx5 is essential for heart development. Development 1999, 126, $1739-1751$. [PubMed]

75. Liu, J.J.; Fan, L.L.; Chen, J.L.; Tan, Z.P.; Yang, Y.F. A novel variant in tbx20 (p.D176n) identified by whole-exome sequencing in combination with a congenital heart disease related gene filter is associated with familial atrial septal defect. J. Zhejiang Univ. Sci. B 2014, 15, 830-837. [CrossRef] [PubMed] 
76. Kirk, E.P.; Sunde, M.; Costa, M.W.; Rankin, S.A.; Wolstein, O.; Castro, M.L.; Butler, T.L.; Hyun, C.; Guo, G.; Otway, R.; et al. Mutations in cardiac t-box factor gene tbx20 are associated with diverse cardiac pathologies, including defects of septation and valvulogenesis and cardiomyopathy. Am. J. Hum. Genet. 2007, 81, 280-291. [CrossRef] [PubMed]

77. Liu, C.; Shen, A.; Li, X.; Jiao, W.; Zhang, X.; Li, Z. T-box transcription factor tbx20 mutations in chinese patients with congenital heart disease. Eur. J. Med. Genet. 2008, 51, 580-587. [CrossRef] [PubMed]

78. Qian, L.; Mohapatra, B.; Akasaka, T.; Liu, J.; Ocorr, K.; Towbin, J.A.; Bodmer, R. Transcription factor neuromancer/tbx20 is required for cardiac function in drosophila with implications for human heart disease. Proc. Natl. Acad. Sci. USA 2008, 105, 19833-19838. [CrossRef] [PubMed]

79. Posch, M.G.; Gramlich, M.; Sunde, M.; Schmitt, K.R.; Lee, S.H.; Richter, S.; Kersten, A.; Perrot, A.; Panek, A.N.; $\mathrm{Al}$ Khatib, I.H.; et al. A gain-of-function tbx20 mutation causes congenital atrial septal defects, patent foramen ovale and cardiac valve defects. J. Med. Genet. 2010, 47, 230-235. [CrossRef] [PubMed]

80. Hammer, S.; Toenjes, M.; Lange, M.; Fischer, J.J.; Dunkel, I.; Mebus, S.; Grimm, C.H.; Hetzer, R.; Berger, F.; Sperling, S. Characterization of tbx20 in human hearts and its regulation by tfap2. J. Cell Biochem. 2008, 104, 1022-1033. [CrossRef] [PubMed]

81. Stennard, F.A.; Costa, M.W.; Elliott, D.A.; Rankin, S.; Haast, S.J.; Lai, D.; McDonald, L.P.; Niederreither, K.; Dolle, P.; Bruneau, B.G.; et al. Cardiac t-box factor tbx20 directly interacts with nkx2-5, gata4, and gata5 in regulation of gene expression in the developing heart. Dev. Biol. 2003, 262, 206-224. [CrossRef]

82. Baldini, A. Digeorge syndrome: An update. Curr. Opin. Cardiol. 2004, 19, 201-204. [CrossRef] [PubMed]

83. Momma, K. Cardiovascular anomalies associated with chromosome 22q11.2 deletion syndrome. Am. J. Cardiol. 2010, 105, 1617-1624. [CrossRef] [PubMed]

84. Yamagishi, H.; Srivastava, D. Unraveling the genetic and developmental mysteries of 22 q11 deletion syndrome. Trends Mol. Med. 2003, 9, 383-389. [CrossRef]

85. Yagi, H.; Furutani, Y.; Hamada, H.; Sasaki, T.; Asakawa, S.; Minoshima, S.; Ichida, F.; Joo, K.; Kimura, M.; Imamura, S.; et al. Role of tbx1 in human del22q11.2 syndrome. Lancet 2003, 362, 1366-1373. [CrossRef]

86. Ataliotis, P.; Ivins, S.; Mohun, T.J.; Scambler, P.J. XTbx1 is a transcriptional activator involved in head and pharyngeal arch development in Xenopus laevis. Dev. Dyn. 2005, 232, 979-991. [CrossRef] [PubMed]

87. Smith, S.J.; Ataliotis, P.; Kotecha, S.; Towers, N.; Sparrow, D.B.; Mohun, T.J. The mlc1v gene provides a transgenic marker of myocardium formation within developing chambers of the xenopus heart. Dev. Dyn. 2005, 232, 1003-1012. [CrossRef] [PubMed]

88. Grossfeld, P.D.; Mattina, T.; Lai, Z.; Favier, R.; Jones, K.L.; Cotter, F.; Jones, C. The 11q terminal deletion disorder: A prospective study of 110 cases. Am. J. Med. Genet. A 2004, 129A, 51-61. [CrossRef] [PubMed]

89. Jacobsen, P.; Hauge, M.; Henningsen, K.; Hobolth, N.; Mikkelsen, M.; Philip, J. An (11;21) translocation in four generations with chromosome 11 abnormalities in the offspring. A clinical, cytogenetical, and gene marker study. Hum. Hered. 1973, 23, 568-585. [CrossRef] [PubMed]

90. Penny, L.A.; Dell'Aquila, M.; Jones, M.C.; Bergoffen, J.; Cunniff, C.; Fryns, J.P.; Grace, E.; Graham, J.M., Jr.; Kousseff, B.; Mattina, T.; et al. Clinical and molecular characterization of patients with distal 11q deletions. Am. J. Hum. Genet. 1995, 56, 676-683. [PubMed]

91. Tunnacliffe, A.; Jones, C.; Le Paslier, D.; Todd, R.; Cherif, D.; Birdsall, M.; Devenish, L.; Yousry, C.; Cotter, F.E.; James, M.R. Localization of jacobsen syndrome breakpoints on a 40-mb physical map of distal chromosome 11q. Genome Res. 1999, 9, 44-52. [PubMed]

92. Ye, M.; Coldren, C.; Liang, X.; Mattina, T.; Goldmuntz, E.; Benson, D.W.; Ivy, D.; Perryman, M.B.; Garrett-Sinha, L.A.; Grossfeld, P. Deletion of ets-1, a gene in the jacobsen syndrome critical region, causes ventricular septal defects and abnormal ventricular morphology in mice. Hum. Mol. Genet. 2010, 19, 648-656. [CrossRef] [PubMed]

93. Nie, S.; Bronner, M.E. Dual developmental role of transcriptional regulator ets1 in xenopus cardiac neural crest vs. Heart mesoderm. Cardiovasc. Res. 2015, 106, 67-75. [CrossRef] [PubMed]

94. Lalani, S.R.; Ware, S.M.; Wang, X.; Zapata, G.; Tian, Q.; Franco, L.M.; Jiang, Z.; Bucasas, K.; Scott, D.A.; Campeau, P.M.; et al. Mctp2 is a dosage-sensitive gene required for cardiac outflow tract development. Hum. Mol. Genet. 2013, 22, 4339-4348. [CrossRef] [PubMed]

95. Davenport, S.L.; Hefner, M.A.; Mitchell, J.A. The spectrum of clinical features in charge syndrome. Clin. Genet. 1986, 29, 298-310. [CrossRef] [PubMed] 
96. Aramaki, M.; Udaka, T.; Kosaki, R.; Makita, Y.; Okamoto, N.; Yoshihashi, H.; Oki, H.; Nanao, K.; Moriyama, N.; Oku, S.; et al. Phenotypic spectrum of charge syndrome with chd7 mutations. J. Pediatr. 2006, 148, 410-414. [CrossRef] [PubMed]

97. Jongmans, M.C.; Admiraal, R.J.; van der Donk, K.P.; Vissers, L.E.; Baas, A.F.; Kapusta, L.; van Hagen, J.M.; Donnai, D.; de Ravel, T.J.; Veltman, J.A.; et al. Charge syndrome: The phenotypic spectrum of mutations in the chd7 gene. J. Med. Genet. 2006, 43, 306-314. [CrossRef] [PubMed]

98. Lalani, S.R.; Safiullah, A.M.; Fernbach, S.D.; Harutyunyan, K.G.; Thaller, C.; Peterson, L.E.; McPherson, J.D.; Gibbs, R.A.; White, L.D.; Hefner, M.; et al. Spectrum of chd7 mutations in 110 individuals with charge syndrome and genotype-phenotype correlation. Am. J. Hum. Genet. 2006, 78, 303-314. [CrossRef] [PubMed]

99. Sanlaville, D.; Etchevers, H.C.; Gonzales, M.; Martinovic, J.; Clement-Ziza, M.; Delezoide, A.L.; Aubry, M.C.; Pelet, A.; Chemouny, S.; Cruaud, C.; et al. Phenotypic spectrum of charge syndrome in fetuses with chd7 truncating mutations correlates with expression during human development. J. Med. Genet. 2006, 43, 211-217. [CrossRef] [PubMed]

100. Vissers, L.E.; van Ravenswaaij, C.M.; Admiraal, R.; Hurst, J.A.; de Vries, B.B.; Janssen, I.M.; van der Vliet, W.A.; Huys, E.H.; de Jong, P.J.; Hamel, B.C.; et al. Mutations in a new member of the chromodomain gene family cause charge syndrome. Nat. Genet. 2004, 36, 955-957. [CrossRef] [PubMed]

101. Wincent, J.; Holmberg, E.; Stromland, K.; Soller, M.; Mirzaei, L.; Djureinovic, T.; Robinson, K.; Anderlid, B.; Schoumans, J. Chd7 mutation spectrum in 28 swedish patients diagnosed with charge syndrome. Clin. Genet. 2008, 74, 31-38. [CrossRef] [PubMed]

102. Bajpai, R.; Chen, D.A.; Rada-Iglesias, A.; Zhang, J.; Xiong, Y.; Helms, J.; Chang, C.P.; Zhao, Y.; Swigut, T.; Wysocka, J. Chd7 cooperates with pbaf to control multipotent neural crest formation. Nature 2010, 463, 958-962. [CrossRef] [PubMed]

103. Schulz, Y.; Wehner, P.; Opitz, L.; Salinas-Riester, G.; Bongers, E.M.; van Ravenswaaij-Arts, C.M.; Wincent, J.; Schoumans, J.; Kohlhase, J.; Borchers, A.; et al. Chd7, the gene mutated in charge syndrome, regulates genes involved in neural crest cell guidance. Hum. Genet. 2014, 133, 997-1009. [CrossRef] [PubMed]

104. McPherson, R.; Pertsemlidis, A.; Kavaslar, N.; Stewart, A.; Roberts, R.; Cox, D.R.; Hinds, D.A.; Pennacchio, L.A.; Tybjaerg-Hansen, A.; Folsom, A.R.; et al. A common allele on chromosome 9 associated with coronary heart disease. Science 2007, 316, 1488-1491. [CrossRef] [PubMed]

105. Helgadottir, A.; Thorleifsson, G.; Manolescu, A.; Gretarsdottir, S.; Blondal, T.; Jonasdottir, A.; Jonasdottir, A.; Sigurdsson, A.; Baker, A.; Palsson, A.; et al. A common variant on chromosome 9p21 affects the risk of myocardial infarction. Science 2007, 316, 1491-1493. [CrossRef] [PubMed]

106. Samani, N.J.; Erdmann, J.; Hall, A.S.; Hengstenberg, C.; Mangino, M.; Mayer, B.; Dixon, R.J.; Meitinger, T.; Braund, P.; Wichmann, H.E.; et al. Genomewide association analysis of coronary artery disease. N. Engl. J. Med. 2007, 357, 443-453. [CrossRef] [PubMed]

107. Ndiaye, N.C.; Azimi Nehzad, M.; El Shamieh, S.; Stathopoulou, M.G.; Visvikis-Siest, S. Cardiovascular diseases and genome-wide association studies. Clin. Chim. Acta 2011, 412, 1697-1701. [CrossRef] [PubMed]

108. Fakhro, K.A.; Choi, M.; Ware, S.M.; Belmont, J.W.; Towbin, J.A.; Lifton, R.P.; Khokha, M.K.; Brueckner, M. Rare copy number variations in congenital heart disease patients identify unique genes in left-right patterning. Proc. Natl. Acad. Sci. USA 2011, 108, 2915-2920. [CrossRef] [PubMed]

109. Greenway, S.C.; Pereira, A.C.; Lin, J.C.; DePalma, S.R.; Israel, S.J.; Mesquita, S.M.; Ergul, E.; Conta, J.H.; Korn, J.M.; McCarroll, S.A.; et al. De novo copy number variants identify new genes and loci in isolated sporadic tetralogy of fallot. Nat. Genet. 2009, 41, 931-935. [CrossRef] [PubMed]

110. Zaidi, S.; Choi, M.; Wakimoto, H.; Ma, L.; Jiang, J.; Overton, J.D.; Romano-Adesman, A.; Bjornson, R.D.; Breitbart, R.E.; Brown, K.K.; et al. De novo mutations in histone-modifying genes in congenital heart disease. Nature 2013, 498, 220-223. [CrossRef] [PubMed]

111. Grammer, T.C.; Liu, K.J.; Mariani, F.V.; Harland, R.M. Use of large-scale expression cloning screens in the Xenopus laevis tadpole to identify gene function. Dev. Biol. 2000, 228, 197-210. [CrossRef] [PubMed]

112. Lundby, A.; Rossin, E.J.; Steffensen, A.B.; Acha, M.R.; Newton-Cheh, C.; Pfeufer, A.; Lynch, S.N.; Consortium, Q.T.I.I.G.; Olesen, S.P.; Brunak, S.; et al. Annotation of loci from genome-wide association studies using tissue-specific quantitative interaction proteomics. Nat. Methods 2014, 11, 868-874. [CrossRef] [PubMed] 
113. Boskovski, M.T.; Yuan, S.; Pedersen, N.B.; Goth, C.K.; Makova, S.; Clausen, H.; Brueckner, M.; Khokha, M.K. The heterotaxy gene galnt11 glycosylates notch to orchestrate cilia type and laterality. Nature 2013, 504, 456-459. [CrossRef] [PubMed]

114. Levy, D.; Ehret, G.B.; Rice, K.; Verwoert, G.C.; Launer, L.J.; Dehghan, A.; Glazer, N.L.; Morrison, A.C.; Johnson, A.D.; Aspelund, T.; et al. Genome-wide association study of blood pressure and hypertension. Nat. Genet. 2009, 41, 677-687. [CrossRef] [PubMed]

115. Takeuchi, F.; Isono, M.; Katsuya, T.; Yamamoto, K.; Yokota, M.; Sugiyama, T.; Nabika, T.; Fujioka, A.; Ohnaka, K.; Asano, H.; et al. Blood pressure and hypertension are associated with 7 loci in the japanese population. Circulation 2010, 121, 2302-2309. [CrossRef] [PubMed]

116. Charpentier, M.S.; Christine, K.S.; Amin, N.M.; Dorr, K.M.; Kushner, E.J.; Bautch, V.L.; Taylor, J.M.; Conlon, F.L. Casz1 promotes vascular assembly and morphogenesis through the direct regulation of an egfl7/rhoa-mediated pathway. Dev. Cell 2013, 25, 132-143. [CrossRef] [PubMed]

117. Christine, K.S.; Conlon, F.L. Vertebrate castor is required for differentiation of cardiac precursor cells at the ventral midline. Dev. Cell 2008, 14, 616-623. [CrossRef] [PubMed]

118. Amin, N.M.; Gibbs, D.; Conlon, F.L. Differential regulation of casz1 protein expression during cardiac and skeletal muscle development. Dev. Dyn. 2014, 243, 948-956. [CrossRef] [PubMed]

119. Sojka, S.; Amin, N.M.; Gibbs, D.; Christine, K.S.; Charpentier, M.S.; Conlon, F.L. Congenital heart disease protein 5 associates with casz1 to maintain myocardial tissue integrity. Development 2014, 141, 3040-3049. [CrossRef] [PubMed]

(C) 2016 by the authors; licensee MDPI, Basel, Switzerland. This article is an open access article distributed under the terms and conditions of the Creative Commons Attribution (CC-BY) license (http://creativecommons.org/licenses/by/4.0/). 